Original Article

\title{
TRADITIONAL SEASONAL HEALTH FOOD PRACTICES IN SOUTHWEST INDIA: NUTRITIONAL AND MEDICINAL PERSPECTIVES
}

\author{
Bhagya B. ${ }^{1}$, Ramakrishna ${ }^{2}{ }^{2} \&$ Sridhar K.R. ${ }^{3}$ \\ ${ }^{1}$ Lecturer, Department of Anatomy, ${ }^{2}$ Professor, Department of Anatomy, Yenepoya University, Deralakatte, \\ M angalore - 575 018, Karnataka, India. ${ }^{3}$ Professor, Department of Biosciences, M angalore University, \\ Mangalagangothri, M angalore - 574 199, Karnataka, India. \\ Correspondence: \\ Sridhar K.R. \\ Professor, Department of Biosciences, Mangalore University, Mangalagangotri, Mangalore - 574199. \\ Phone : $+918242287262 . \quad$ E-mail : sirikr@yahoo.com
}

\begin{abstract}
:
The unique traditional practices of people belonging to Dakshina Kannada of Karnataka (Southwest India) utilize a variety of plant species for nutritional and medicinal purposes. This indigenous traditional knowledge (folklore/plantlore of food and medicine) is usually associated with rituals like 'Aati Amavasye'. Several plant species are used in a specific season as nutritional and or medicinal source. In changing time, such unique practices are disappearing and restricted largely to remote rural areas. Attention to identify the nutritional novelties, medicinal uniqueness, mode of formulations, and effectiveness of plant species need further exploration.
\end{abstract}

Keywords: Traditional knowledge, plantlore, nutraceutical, ethnonutrition, ethnomedicine

\section{Introduction :}

Integration of indigenous and scientific knowledge for conservation of bioresources has taken shape by three recent major international conventions ${ }^{1-3}$. Although the definition of indigenous ecological knowledge is not universally accepted, it is reasonable to understand the practice or belief evolved and adapted several generations by cultural transmission ${ }^{4}$. The Convention on Biological Diversity (CBD) in global strategic plan for biodiversity is targeted to integrate traditional knowledge for conservation and sustainable utilization of biodiversity ${ }^{3}$.

Southwest region of India is endowed with diverse flora and fauna Many of the communities in this part of the country depend on the traditional food sources and medicine for curing Access this article online Quick Response Code

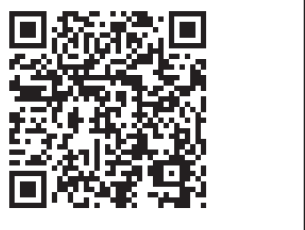

nutraceuticals of these communities. Such practices are usually linked to different seasons as well as the rituals confined to this region. The selection, formulation, mode of preparation and doses administered as food/beverage/medicine seem to have unique historical and traditional background. Use of different plant species for nutritional or medicinal purpose has an important role in the cultural evolution of the coastal dwellers.

The lunar calendar is widely observed and followed which is divided into six seasons (or ruthu). Each season has been characterized by an important component of taste (e.g. sweet, sour, salt, bitter, pungent and astringent) ${ }^{5}$. During the Varsha ruthu (rainy season) (Ashadha, lunar calendar; or Aati, solar calendar), many traditional food and medicinally-valued plant parts will be utilized. Usually, celebrations are prohibited during the month of Aati masa as it has been considered as an inauspicious month. This paper highlights the traditional nutritional and medicinal perspectives of some plant species of Dakshina Kannada.

\section{Methods:}

Cultural practices of different communities and ethnic groups were interviewed directly to record seasonal 
ethnonutritional, ethnomedicinal, traditional rituals and their socioeconomic values with precise questionnaire during anuary-December 2011. The information gathered was compared with the available classical literature. M ode of preparations or formulations of traditional food, medicine and their importance were also documented. The plant species used were collected and identified based on monographs ${ }^{6.8}$ and confirmed identification with taxonomists.

\section{Results:}

Aati amavasye

In Dakshina Kannada, during Ashadha masa ('Aati masa' in Tulu language) on the new moon day, an annual ritual (Aati amavasye) of drinking the concoction made out of bark of Alstonia scholaris (called 'Indian devil tree') is in practice. This is a mass ritual observed by all irrespective of their religion or community or caste. The evergreen perennial tree species A. scholaris is native to the Indian subcontinent and Southeast Asia. The bark of this tree is washed in water on the previous day of bark extraction, a holy thread is tied around the tree and prayers are offered worshiping the tree to store all the medicinal properties in it. The spirit 'Aati Kalenja' is believed to protect people from diseases during the month of Aati by storing all the medicinal properties in the devil tree on that specific day. On the dark moon day, after bath prior to sunrise devotees approach the devil tree and cut its bark with a clean stone (use of knife or any metal implements are known to cause chemical reaction of concoction to be prepared) (Fig. 1a). The inner fleshy part of the bark will be pealed out and grind with pepper, cumin and garlic to prepare a milky bitter concoction. Heating white pebbles on charcoal and addition to the concoction believed to eliminate the toxic constituents. Later, the concoction will be filtered and consumed prior to have food or beverage. Depending on the age the dosage will be reduced to half or one fourth for children. Consumption of the concoction is followed by a sweet dish made out of raw rice, jaggery and coconut milk.

It is believed that in the rainy season people will succumb for several illnesses. Thus, consumption of the milky bitter concoction of devil tree is assumed to stimulate the immune system and prevent diseases. The devil tree is believed to have 1,001 medicinal properties. The bark of devil tree is known to consists of several alkaloids (e.g. ditamine, echitanine, echitamidine, picrinine and tubotaiwine) used as an alternative to quinine. The concoction of the bark is also used to treat anemia, menstrual disorders, malaria, fever, colic and diarrhea, while the decoction of leaves used in treatment of Beriberi ${ }^{6}$. The latex of this tree is also used to cure ulcers, soars and arthritis ${ }^{9}$.

\section{Aati Padinema}

On the $18^{\text {th }}$ day of Aati masa, a celebration called 'Aati Padinema' will be observed in Dakshina Kannada, while 'Kakkada Padinetta' in the Kodagu. That day is the beginning of agricultural activities. It is also celebrated as the festival of ayurvedic herbs in different regions. According to the tradition, Aati Padinema will be marked by the preparation and consumption of a sweet dish made out of leaves of Justicia wynaadensis ('aati soppu' or 'maddu soppu'). The leaves of this shrub are believed to imbibe 18 medicinal principles useful to improve human health. A pharmaceutical US patent has been granted for the use of J. wynaadensis (http://www.pharmcast.com/Patents/ Yr2002/April2002/040202/6365411_Cholesterol040202.h tm), which lowers cellular cholesterol, cholesteryl ester concentration and also possess inhibitory property on the uptake of low density lipids (LDL) by the macrophage cell line.

\section{Aati masa}

Another common delicacy preferred to consume during this season is the tender bamboo shoots (Bambusa arundinacea) ('kanile') ${ }^{6}$ (Fig. 1e). These shoots will not be consumed on the day of collection due to toxic hydrocyanic acid. After cutting the shoots in to small pieces, soaked in water for two days to eliminate the toxins and the pieces are used to prepare various dishes consisting of a strong pleasant characteristic aroma. The shoot of the plant is reported to possess anti-inflammatory, antiulcer, antidiabetic, antioxidant, anthelmintic, astringent, emmengogue activity ${ }^{10}$. 
Some of the commonly used plants for consumption in traditional way include leaves of Cassia tora ('tajank': leaves), Colocasia esculenta ('kesuvu': rhizome, stem, leaves), Moringa oleifera (drumstick: pods, leaves, flowers), Amorphophallus paeoniifolius (katkene: petiole) (Fig. 1b, c), Cayratia mollissima (Kanakallate: raw fruits) (Fig. 1f) (Table 1). The dish Patrode is a delicacy and it will be prepared from the leaves of $C$. esculenta. Different fermented rice dishes are prepared using the leaves of Curcuma longa (turmeric, 'arishina'), Musa acuminata (banana, 'baale'), Tectona grandis (teak, 'saguvani'), Artocarpus heterophyllus (jackfruit, 'halasu') (Fig. 1d) and Erythrina indica (Indian coral tree or 'hongare'). Leaves of screw pine (Pandanus unipapilatus) ('kedige' or 'mundige') (Fig. 1g) are widely used to prepare a fermented food similar to the rice dish 'idli' ('mude') during rainy season (Table 1). The leaves are known to possess medicinal properties and also incorporate its aroma to the dish. As screw pine leaves are rough with spiny edges, spines will be removed, cut into desired size, cleaned in water, rolled and

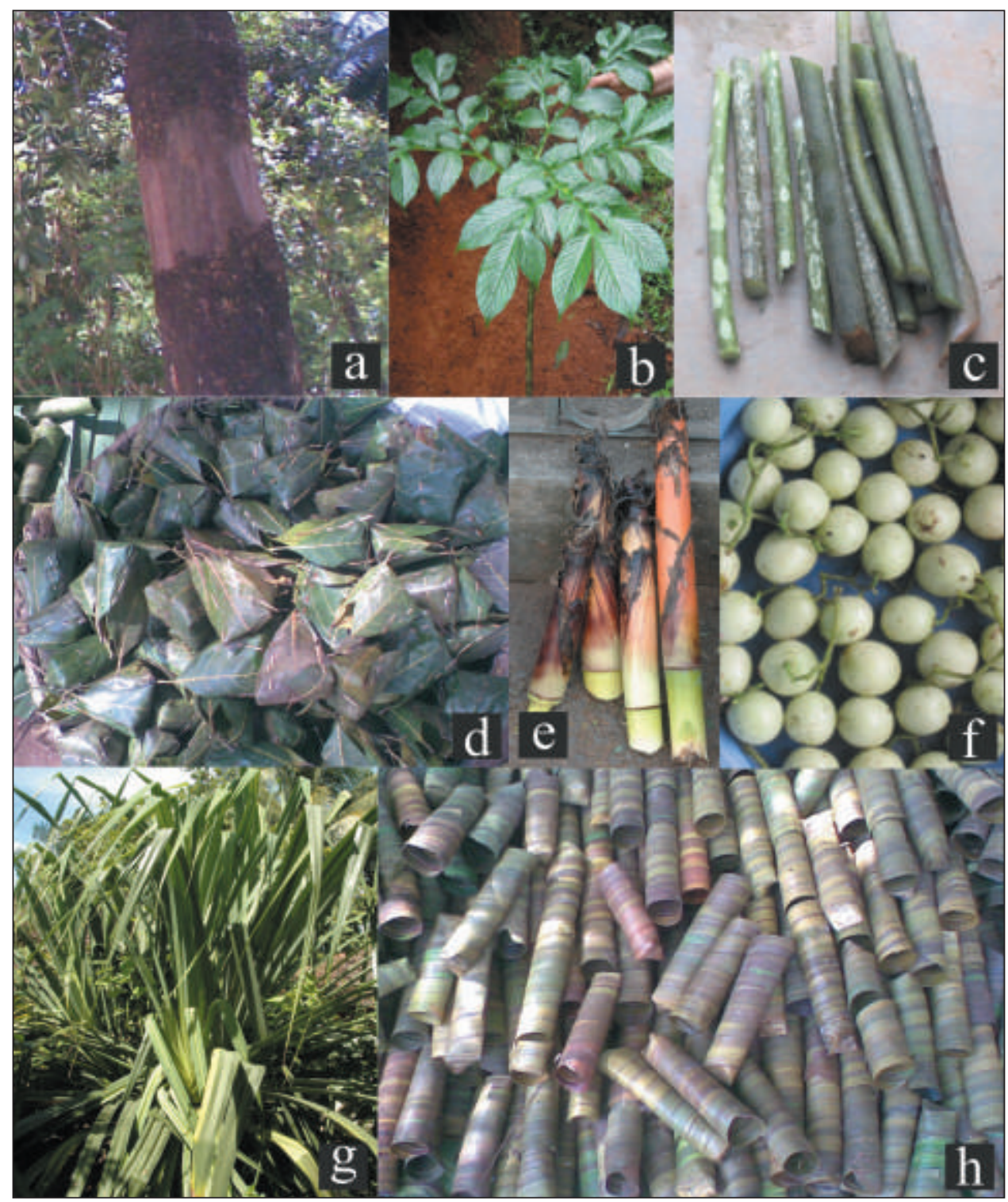

Fig 1. Alstonia scholaris (devil tree) showing patch of bark extraction (a); Amorphopholus paeoniifolius plant (b), A. paeoniifolius petiole (c); baked rice dish 'kottige' in cones of jackfruit (Artocarpus heterophylus) leaves (d); harvested tender bamboo (Bambusa arundanacea) shoots (e); fruits of Cayratia mollissima (f); Pandanus unipapilatus (screw pine) plant (g) and cylindrical containers made out up of screw pine leaves for preparation of baked rice dish 'mude' (h). 
Table 1. Plant species traditionally used as food or nutraceutical in Dakshina Kannada, Southwest India.

\begin{tabular}{|l|l|l|l|l|}
\hline Botanical name & $\begin{array}{l}\text { Vernacular name } \\
\text { (Tulu/ Kannada) }\end{array}$ & Part of plant used & Name of dish & Figure \\
\hline Alstonia scholaris & 'Haale mara' & Bark & Concoction (beverage) & $1 \mathrm{a}$ \\
\hline Amorphophallus paeoniifolius & 'Katkene' & Petiole & 'Dosa' (fermented roasted rice) & $1 \mathrm{~b}, \mathrm{c}$ \\
\hline Artocarpus heterophyllus & 'Halasu' & Leaves to cover food & 'Kottige' (fermented baked rice) & $1 \mathrm{~d}$ \\
\hline Bambusa arundinacea & 'Kanile' & Tender shoots & Curry & $1 \mathrm{e}$ \\
\hline Cassia tora & 'Tajank' & Leaves & 'Patrode' (fried dish) and curry & - \\
\hline Cayratia mollissima & 'Kanakallate' & Fruits & Curry ('majjigehuli' with curds) & $1 \mathrm{f}$ \\
\hline Colocasia esculenta & 'Kesuvu' & Leaves & 'Patrode' (fried dish) & - \\
\hline Curcuma longa & 'Arishina' & Leaves to cover food & 'Kadubu' (fermented baked rice) & - \\
\hline Erythrina indica & 'Hongare' & Leaves to cover food & 'Kadubu' (fermented baked rice) & - \\
\hline Justicia wynaadensis & 'Aati soppu' & Leaves & Sweet dish & - \\
\hline M oringa oleifera & 'Nuggekayi' & Pods, leaves and flowers & Curry and various foods & - \\
\hline M usa acuminata & 'Baale' & Leaves to cover food & 'Genesale' (fermented baked rice) & - \\
\hline Pandanus unipapilatus & 'Kedige' & Leaves to cover food & 'Mude' (fermented baked rice) & $1 \mathrm{~g}, \mathrm{~h}$ \\
\hline Tectona grandis & 'Saguvani' & Leaves to cover food & 'Genesale' (fermented baked rice) & - \\
\hline
\end{tabular}

weaved like ribbon after blanching in fire (Fig. 1h). The entire plant is diuretic, leaves are used in treating skin diseases and roots have anti-diabetic properties.

Traditional folkdances

The 'Aati Kalenja' is one of the traditional dances of Tulu Nadu practiced by the Nalike community. A person dresses up as a mark of spirit and is believed to rid away the village from the anti-elements during the Aati masa. It is believed that the practice of this ritual by the people helps to keep away the dangers of the evil spirits. The man who involved in ritualistic dance decorated with tender coconut leaves, anklets, colorful cloths, long cap made by areca (Areca catechu) spathe and the face will be full of colorful designs (Figure 2). By holding an umbrella made up of leaves and decorated with flowers, the ritual performer dancing, singing and visiting the houses. In return, the ritual performer is rewarded with paddy, rice, coconut, turmeric and charcoal by the devotees. 'Sona Jogi' (Figure 3) is another art form where one of the member dances and others sing songs. They use traditional instruments for music. They gather rice, coconut and other grocery during their visit to the houses.

\section{Conclusion :}

Documentation of indigenous traditional knowledge especially plant selection, season in which utilized, plant part used for nutrition/medicine and mode of processing assumes prime importance. Several rituals have directly or indirectly linked with regional cultivation and conservation of biodiversity of specific plant species by local people. But with the changing time, the unique art 'Aati Kalenja' and other traditional rituals are largely restricted to the remote rural areas and seem to be vanishing. $M$ any native plant species are being neglected, destroyed or replaced by exotic plant species. Thus, the diversity of regionally valuable plants and their associated ethnonutritional and ethonomedicinal knowledge is dwindling. Documentation and developing databases of history of the traditional knowledge, plantlore and cultural practices towards human nutrition and therapy through various indigenous plant species may provide a greater dimension to conserve the tradition as well as plant diversity.

\section{Acknowledgements:}

Authors are thankful to the rural participants who contributed for this synthesis. We sincerely acknowledge the help rendered by Prof. K. Gopalkrishna Bhat, Poornaprajna College, Udupi for identification of plant species. 


\section{References}

1. Millennium Ecosystem Assessment. Ecosystems and Human Wellbeing: Synthesis. Island Press, Washington, DC. 2005.

2. Finlayson CM, Carbonell M, Alarcó T, Masardule O. Analysis of Ramsar's guidelines for establishing and strengthening local communities' and Indigenous peoples' participation in the management of wetlands (Resolution VII.8). In Science and Local Communities - Strengthening Partnerships for Effective Wetland Management. Carbonell, M., Nathai-Gyan, N. and Finlayson C.M. (eds), 2001; 51-56, Ducks Unlimited Inc., M emphis, USA.

3. CBD. Convention for Biological Diversity - Strategic Plan for Biodiversity 2011-2020: http://www.cbd.int/deci sion/cop/?id= 12268. 2011.

4. Berkes F. Sacred Ecology: Traditional Ecological Knowledge and M anagement Systems. Taylor and Frances, Philadelphia and London. 2008.
5. Yoganarasimhan SN. M edicinal Plants of India. Volume \#1 - Karnataka, Interline Publishing Pvt. Ltd., Bangalore, India. 1996.

6. Jain SK. M edicinal Plants. National Book Trust, New Delhi, India. 1996.

7. Shetty BV, Kaveriappa KM , Bhat KG. Plant Resources of Western Ghats and Lowlands of Dakshina Kannada and Udupi Districts, Pilikula Nisarga Dhama Society, M angalore, India. 2002.

8. Bhat KG. Flora of Udupi District, Indian Naturalist, Udupi, India. 2003.

9. Murthy KRS. Astanga Samgraha of Vagbhata. Chankhambha Orientalia, Varanasi, India. 2003.

10.Jaimik RD, Nimish PL, Ritesh PG, Jivani NP, Nayna MB. Phytopharmacological properties of Bambusa arundinacea as a potential medicinal tree: An overview. Journal of Applied Pharmaceutical Science. 2011;1(10): 27-31 